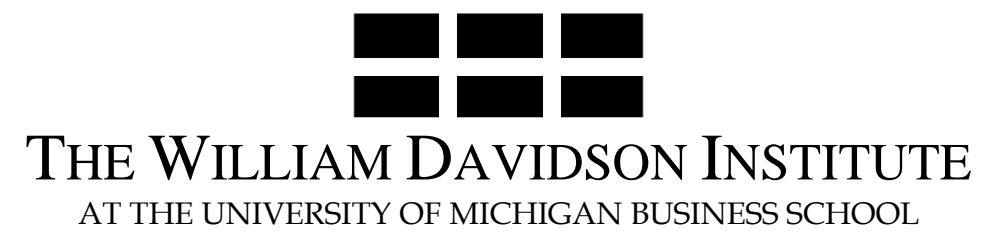

\title{
IMPACT OF REGULATED PRICE ADJUSTMENTS ON PRICE VARIABILITY IN A VERY LOW INFLATION TRANSITION ECONOMY: CASE OF ARMENIA
}

\author{
By: Aghassi Mkrtchyan
}

William Davidson Institute Working Paper Number 731

November 2004 


\title{
IMPACT OF REGULATED PRICE ADJUSTMENTS ON PRICE VARIABILITY IN A VERY LOW INFLATION TRANSITION ECONOMY: CASE OF ARMENIA
}

\author{
Aghassi Mkrtchyan
}

2004, Armenia

\begin{abstract}
The impact of macroeconomic management (monetary policy) and administrative price adjustments on price variability in a low inflation economy characterized by relatively frequent administrative price adjustments is examined. Fluctuations of market determined prices, prices of agricultural goods in particular, are linked to the lack of synchronization between administrative price changes and monetary policy. If monetary policy does not account for expected changes in administrative prices, demand in "free" goods markets will shift causing fluctuation of prices for agricultural goods, because the supply of these goods is highly inelastic in Armenia. The findings contribute to a better understanding of agricultural price variability during 1998-2002. The impact of macroeconomic policy and structural adjustments on income distribution and rural poverty incidence are also examined. This research has immediate policy implications since Armenia will undergo major upward price adjustments for goods and services with regulated prices, which may have a negative impact on income distribution if aggregate demand management is unchanged.
\end{abstract}

Key words: Inflation, price variability, regulated prices

JEL Codes: E31, E61 


\section{Contents}

1. Introduction

2. Relative Price Developments in Armenia 1998-2002: Statistical Evidence

Choosing the Time period

Groupings and Weights

Cumulative Changes in Individual Prices in 1998-2002

Identification of Administratively Regulated Price Changes

3. Price Variability: Initial Findings

6. Conclusions and Policy Implications 


\section{Introduction}

The paper examines the impact of monetary policy and administrative price adjustments on price variability in a low inflation economy characterized by relatively frequent administrative price adjustments. In 1998-2002, price variability in Armenia was quite significant. Not only the distribution of relative prices was uneven in this period, which can be explained by major adjustments in administrative prices, but also price variability within the groups of "free” goods (prices for which are determined in the market) was very significant, driven by fluctuations in prices for main agricultural goods.

The statistical evidence shows that variability within the group of "free" goods is mainly lead by fluctuation of agricultural goods, which have been declining in the period of 1998-1999, and recovering in following years. The statistical evidence also shows that agricultural prices declined in the time when upward regulated price adjustments coincided with tight monetary policy, while agricultural prices recovered in the time of combination of expansionary monetary policy with no major revision of regulated prices.

The paper examines whether tight monetary policy in the time of major price adjustments causes increased variability of individual inflations by pushing the prices of certain "free" goods down and whether relaxed monetary policy causes increased variability of prices in time of constant regulated prices by pushing prices of "free” goods up. The paper finds that if monetary policy does not account for expected changes in administrative prices, demand in "free" goods market will shift causing fluctuations of prices for agricultural goods, as the supply of these goods is highly inelastic in Armenia.

The findings of the paper contribute to a better understanding of agricultural price variability during 1998-2002. The impact of macroeconomic policy and structural adjustments on income distribution and rural poverty incidence are also examined. This research has immediate policy implications since Armenia will undergo major upward price adjustments for goods and services with regulated prices, which may have a negative impact on income distribution if aggregate demand management is unchanged. 
In the second section I present the main dynamics of relative price changes in Armenia in 19982002, particularly examining the behavior of agricultural prices. The third section analyzes the price variability and possible factors behind it. Variances of individual inflations are considered and the contributions from administratively regulated versus market determined prices are studied. In the fourth section I describe a theoretical framework that has been used to analyze this problem and apply it to the specifics of the situation in Armenia. In the fifth empirical section I test whether price variability can be explained by the lack of policy synchronization between demand management and administrated price changes. Further I examine the possible mechanisms behind this relationship. The final section summarizes my main conclusions, including those that relate to the impact of relative price changes on income distribution and policy implications for monetary policy and administrative price adjustments.

\section{Relative Price Developments in Armenia 1998-2002: Statistical Evidence}

Choosing the time period. There are several reasons for examining the time period 1998-2002. There are three important factors for dividing recent economic history into the period of prior to 1998 period and 1998-2002. These are the change in the exchange rate regime, tax administration and the general stance of macroeconomic policy:

- In mid-1996 the Central Bank announced its decision to change the exchange rate regime, switching from de-facto fixed exchange rate regime to a generally "free" floating exchange rate regime. This new policy was introduced in practice starting the end of 1996, when the Central Bank had negative net foreign assets and generally ceased interventions in the foreign exchange market. It was a period of large direct crediting to the Government and a sharp depreciation of national currency took place. Depreciation continued in 1997 as well, causing adjustments in prices and inflation above 20\%. By the end of 1997 the “exchange rate related” adjustments were mostly completed.

- 1997 was marked by the establishment of new tax policies, and the first major steps of improvement in tax administration, which resulted in higher indirect tax revenues as a proportion of GDP. These developments substantially changed the pattern of price formation since then. 
- By the end of 1997 a new relationship between the Central Bank and Government was established, which prohibited direct credits from the Central Bank to finance the budget deficits. Moreover, a ceiling for the Government's liabilities against the Central Bank was set, which implies no deficit financing by the Central Bank on annual basis even through the purchase of t-bills in the secondary market. As a result, starting in 1998 monetary policy was "tied" to foreign flows. This became the main factor of generally contractionary monetary policy in 1998-1999, when as a result of the Russian crisis private remittances significantly decreased and major external financing of the budget deficit was delayed, as Government did not meet its commitments in key areas of structural reforms.

Groupings and weights. On the basis of the list of individual components of the CPI basket 19 groups were constructed. These slightly differ from the groupings usually presented by the National Statistics Service. In particular, imported fruits were excluded from "fruits and vegetables”, and a new group of imported food was constructed, which includes only imported goods for which there is no domestic substitution. Table 1 shows the groups and weights of each group in the total CPI basket in the period of 98-02.

During 1998-2002 the official CPI is calculated based on different weights for individual goods for each year, based upon consumer behavior surveys conducted by the National Statistical Service (NSS) every year.

Table 2.1 Annual weights and average for 1998-2002

\begin{tabular}{|l|c|c|c|c|c|c|}
\hline & 1998 & 1999 & 2000 & 2001 & 2002 & $\begin{array}{c}\text { Average } \\
\text { weights, } \\
1998-02\end{array}$ \\
\hline Bread, cereals & 21,4 & 26,0 & 22,7 & 21,58 & 20,16 & 22,4 \\
\hline Fruits and vegetables & 13,1 & 7,0 & 6,4 & 7,33 & 8,92 & 8,5 \\
\hline Meat products & 5,8 & 8,3 & 9,4 & 9,36 & 10,76 & 8,7 \\
\hline Eggs and dairy & 5,1 & 6,0 & 8,0 & 7,84 & 9,16 & 7,2 \\
\hline Food & 4,7 & 5,7 & 4,9 & 4,85 & 5,03 & 5,0 \\
\hline Only imported food & 6,5 & 7,1 & 7,0 & 6,98 & 5,99 & 6,7 \\
\hline Non-alcohol drinks & 0,2 & 0,5 & 0,5 & 0,39 & 0,33 & 0,4 \\
\hline Alcohol & 1,3 & 1,7 & 1,3 & 1,32 & 1,21 & 1,4 \\
\hline Tobacco & 3,3 & 4,4 & 10,4 & 10,62 & 7,12 & 7,2 \\
\hline Gasoline/diesel & 0,2 & 2,0 & 2,1 & 2,69 & 1,36 & 1,7 \\
\hline Pharmacy & 3,5 & 1,8 & 2,7 & 2,60 & 2,76 & 2,7 \\
\hline Services & 3,5 & 3,1 & 4,1 & 4,21 & 2,89 & 3,6 \\
\hline Utilities & 6,4 & 8,0 & 4,7 & 4,72 & 6,33 & 6,0 \\
\hline
\end{tabular}




\begin{tabular}{|l|c|c|c|c|c|c|}
\hline Transport & 3,1 & 2,7 & 2,6 & 2,70 & 2,92 & 2,8 \\
\hline Communication & 0,7 & 1,4 & 0,7 & 0,75 & 1,30 & 1,0 \\
\hline Clothing & 10,0 & 7,5 & 5,6 & 5,36 & 6,82 & 7,1 \\
\hline Fuel for home use & 1,8 & 1,7 & 0,4 & 0,47 & 0,62 & 1,0 \\
\hline Education, culture & 2,4 & 1,6 & 1,0 & 1,07 & 1,33 & 1,5 \\
\hline Other goods & 6,8 & 3,7 & 5,2 & 5,19 & 5,00 & 5,2 \\
\hline
\end{tabular}

Three sets of indices were calculated: one with changing weights and two with constant weights, of which first is based on the average weights of 1998-2002 and the second is based on 2002 weights.

Table 2.2 Three sets of individual inflation derived from different weights ${ }^{1}$

\begin{tabular}{|c|c|c|c|c|c|c|c|c|c|c|c|c|c|c|c|}
\hline & \multicolumn{3}{|c|}{1998} & \multicolumn{3}{|c|}{1999} & \multicolumn{3}{|c|}{2000} & \multicolumn{3}{|c|}{2001} & \multicolumn{3}{|c|}{2002} \\
\hline & $\begin{array}{l}\text { changing }(\mathrm{o} \\
\text { fficial) }\end{array}$ & $\begin{array}{l}\text { constant } \\
\text { average }\end{array}$ & $\begin{array}{c}\text { constant } \\
2002\end{array}$ & $\begin{array}{l}\text { changing(o } \\
\text { fficial) }\end{array}$ & $\begin{array}{l}\text { constant } \\
\text { average }\end{array}$ & $\begin{array}{c}\text { constant } \\
2002\end{array}$ & $\begin{array}{l}\text { changing(o } \\
\text { fficial) }\end{array}$ & $\begin{array}{l}\text { constant } \\
\text { average }\end{array}$ & $\begin{array}{c}\text { constant } \\
2002\end{array}$ & $\begin{array}{l}\text { changing(o } \\
\text { fficial) }\end{array}$ & $\begin{array}{l}\text { Constant } \\
\text { average }\end{array}$ & $\begin{array}{c}\text { Constant } \\
2002 \\
\end{array}$ & $\begin{array}{l}\text { changing(o } \\
\text { fficial) }\end{array}$ & $\begin{array}{l}\text { constant } \\
\text { average }\end{array}$ & $\begin{array}{c}\text { constant } \\
2002\end{array}$ \\
\hline Bread, carrels & 6,4 & 5,6 & 4,5 & 3,3 & 3,1 & 3,3 & 4,4 & 4,4 & 4,6 & 1,3 & 1,2 & 1,3 & 1,6 & 1,4 - & 1,6 \\
\hline Fruits and vegetables & - $\quad 17,1$ & 16,6 & 16,2 & - $\quad 15,1$ & 14,3 . & $-\quad 16,1$ & 15,6 & 17,3 & 22,9 & 19,2 & 37,9 & 31,4 & 17,1 & 18,6 & 17,1 \\
\hline Meat products & 5,5 & 3,3 & 3,0 & 6,9 & 6,7 & 6,8 & 0,4 & 0,4 & 1,8 & 12,2 & 12,0 & 12,3 & 1,6 & 1,9 & 1,6 \\
\hline Eggs and diary & 8,1 & 6,5 & 6,3 & 4,3 & 4,4 & 4,3 & 2,2 & 2,0 & 1,5 & 1,5 & 1,3 & 1,5 & 3,4 & 3,3 & 3,4 \\
\hline Food & 4,6 & 3,7 & 3,1 & 7,9 & 7,3 & 6,4 & 2,8 & 2,7 & 1,8 & 0,3 & 0,2 & 0,3 & 1,7 & 2,2 & 1,7 \\
\hline Only imported food & 7,4 & 6,3 & 7,0 & 6,7 & 6,9 & 7,8 & 0,1 & 1,0 & 1,7 & 1,4 & 1,3 & 1,7 & 3,6 & 2,8 & 3,6 \\
\hline Non-alcohol drinks & 1,4 & 1,9 & 1,7 & 0,5 & 0,0 & 0,1 & 2,1 & 2,0 & 2,2 & 1,8 & 2,1 & 1,5 & 3,2 & 3,1 & 3,2 \\
\hline Alcohol & 0,6 & 0,7 & 0,1 & 2,2 & 1,9 & 0,3 & 1,6 & 1,4 & 0,9 & 1,0 & 1,5 & 3,8 & 3,8 & 4,2 & 3,8 \\
\hline Tobacco & 9,7 & 9,8 & 10,2 & 59,6 & 65,4 & 69,1 & 2,6 & 1,6 & 2,6 & 3,8 & 3,1 & 3,2 & 10,1 & 6,9 & 10,1 \\
\hline Gasoline/diesel & 6,1 & 3,0 & 3,1 & 27,4 & 27,2 & 27,2 & 25,9 & 25,9 & 25,9 & 13,0 & 12,9 & 12,9 & 6,7 & 6,7 & 6,7 \\
\hline Pharmacy & 1,3 & 0,4 & 0,1 & 0,3 & 1,7 & 2,2 & 2,9 & 1,9 & 3,0 & 3,0 & 2,0 & 3,3 & 3,5 & 2,7 . & 3,5 \\
\hline Services & 16,9 & 10,3 & 8,5 & 2,9 & 2,0 & 0,9 & 3,0 & 2,2 & 0,1 & 2,6 & 1,7 & 0,6 & 1,0 & 0,6 & 1,0 \\
\hline Utilities & 4,9 & 4,7 & 4,6 & 18,2 & 17,7 & 17,6 & 0,1 & 0,1 & 0,1 & 0,1 & 0,1 & 0,1 & 0,1 & 0,1 & 0,1 \\
\hline Transport & 0,6 & 1,4 & 0,9 & 0,4 & 0,8 & 1,4 & 2,7 & 3,3 & 4,2 & 0,3 & 0,2 & 0,4 & 0,7 & 0,5 & 0,7 \\
\hline Communication & 14,2 & 13,7 & 12,0 & 53,2 & 51,3 & 48,4 & 2,1 & 2,2 & 1,9 & 1,6 & 2,0 & 1,8 & 15,2 & 15,7 & 15,2 \\
\hline Clothing's & 1,3 & 1,6 & 1,5 & 0,6 & 1,1 . & 0,7 & 4,0 & 4,1 & 4,4 & 0,8 & 0,9 & 1,3 & 3,4 & 3,5 & 3,4 \\
\hline Fuel for home use & 1,0 & 1,3 & 2,4 & 11,1 & 9,9 & 5,9 & 12,8 & 12,5 & 18,2 & 11,4 & 8,4 & 18,0 & 23,5 & 21,1 & 23,5 \\
\hline Education, culture & 0,6 & 0,6 & 1,2 & 15,0 & 11,5 & 6,5 & 2,3 & 2,7 & 3,0 & 3,7 & 3,5 & 3,2 & 3,2 & 3,9 & 3,2 \\
\hline Other goods & 0,1 & 0,3 & 0,4 & 2,7 & 3,7 & 3,3 & 0,7 & 1,0 & 1,0 & 2,2 & 1,9 & 2,6 & 0,7 & 0,9 & 0,7 \\
\hline Total CPI & 1,4 & 1,2 & 1,8 & 2,0 & 3,1 & 2,9 & 0,4 & 0,8 & 1,2 & 2,9 & 4,5 & 3,9 & 2,0 & 2,4 & 2.0 \\
\hline
\end{tabular}

Table 2 shows the annual inflation for each group of goods and for total CPI calculated on the basis of the three different weights. Changes in the weights have quite significant impact, since they affect not only on the aggregate CPI, but also on the indices of the constructed subgroups. The most extreme difference is in 2001 for "fruits and vegetables" for which official statistics with changing weights (the first column) shows 19.2\% annual inflation, while inflation based upon average weights and 2002 weights are 37.9 and 31.4\% respectively. However, there are two

\footnotetext{
${ }^{1}$ Shadowed cells indicate the largest discrepancies in individual inflations derived from different weights
} 
reasons why changing weights should not be used in empirical studies. First, changing weights are appropriate when we want to study price inflation from the consumers' point of view, however, while looking at the dynamics of individual prices, we don't want to contaminate the data with changes in other factors. Second, changes in weights reflect the continuing improvements in consumer basket survey methodology, rather than true changes in the structure of consumption. It is quite unlikely that drastic changes in consumption preferences might occur in the relatively short period of 1998-2002. For instance, while the share of gasoline in the CPI basket was $0.2 \%$ in 1998, it was 2.1\% in 2000; even the $50 \%$ increase in the price of gasoline cannot explain the ten-fold increase in the gasoline weight in the CPI.

Cumulative changes in individual prices in 1998-2002. To examine the dynamics of individual prices and cumulative changes in the period of 1998-2002 descriptive statistics and empirical analysis use indices based upon average weights of 1998-2002.

As in other transition countries, Armenia has experienced drastic changes in relative prices. Most adjustments took place in the early and mid 90s when liberalization of prices was still underway. Although, most of prices were liberalized before 1998 and inflation during 1998-2002 was very low (1.5\% average annual inflation), drastic changes occurred in relative prices in the period of 1998-2002 as well. In particular, there were significant increases in administratively regulated prices, the introduction of indirect taxes or increases of indirect tax rates and fluctuations in international commodities markets. Table 3 shows the quarterly indices of the 19 individual groups.

Table 2.3. Individual indices

\begin{tabular}{|c|c|c|c|c|c|c|c|c|c|c|c|c|c|c|c|c|c|c|c|c|c|}
\hline & $\begin{array}{l}\text { Q4 } \\
97\end{array}$ & $\begin{array}{l}\text { Q1 } \\
98 \\
\end{array}$ & \begin{tabular}{|l|}
22 \\
97
\end{tabular} & $\begin{array}{l}\text { Q3 } \\
98 \\
\end{array}$ & \begin{tabular}{|l} 
Q4 \\
98 \\
\end{tabular} & $\begin{array}{l}\text { Q1 } \\
99\end{array}$ & $\begin{array}{l}\text { Q2 } \\
99\end{array}$ & \begin{tabular}{|l} 
Q3 \\
99 \\
\end{tabular} & $\begin{array}{l}\text { Q4 } \\
99 \\
\end{array}$ & $\begin{array}{l}\text { Q1 } \\
\text { o0 }\end{array}$ & \begin{tabular}{|l|}
$\mathrm{Q} 2$ \\
00 \\
\end{tabular} & $\begin{array}{l}\text { Q3 } \\
00\end{array}$ & $\begin{array}{l}\mathrm{Q} 4 \\
00 \\
\end{array}$ & $\begin{array}{l}\text { Q1 } \\
\text { O1 }\end{array}$ & $\begin{array}{l}\mathrm{Q} 2 \\
\mathrm{O} 1\end{array}$ & $\begin{array}{l}\text { Q3 } \\
01\end{array}$ & \begin{tabular}{|l}
$\mathrm{Q} 4$ \\
01 \\
\end{tabular} & $\begin{array}{l}1 \\
02\end{array}$ & $\begin{array}{l}\text { Q2 } \\
02\end{array}$ & $\begin{array}{l}\text { Q3 } \\
\text { 02 }\end{array}$ & $\begin{array}{l}\text { Q4 } \\
02\end{array}$ \\
\hline Brea & 00,0 & 112,2 & 107,2 & 106,3 & 105,6 & 4,4 & 102,0 & 102,6 & 102,3 & 101,4 & 100,6 & $6 \quad 97,5$ & $97,8^{0}$ & $8 \quad 97,9$ & 97,7 & 96,8 & 96,6 & 696,3 & $3 \quad 95,6$ & 94,7 & 95,3 \\
\hline & 0 & 129,1 & 101,6 & 60,2 & 83,4 & 105,8 & 121,3 & 53,2 & 71,5 & 95,2 & 87,2 & $2 \quad 61,2$ & 83,9 & 34,2 & 126,3 & \begin{tabular}{|l|l|}
3 \\
\end{tabular} & 115,8 & \begin{tabular}{l|l}
8141,9 \\
\end{tabular} & $9 \quad 166,1$ & $\begin{array}{l}43,0 \\
\end{array}$ & 137 \\
\hline $\mathrm{Me}$ & 00,0 & 101,8 & 102,8 & 98,3 & 96,7 & 93,3 & 95,1 & 93,7 & 90,3 & 90,7 & 89,1 & $1.86,4$ & 90,7 & 98,2 & 99,9 & 97,2 & 101,6 & 101,5 & 107,9 & 96,5 & 103,5 \\
\hline Eggs & 0,0 & 100,4 & 93,4 & 91,9 & 93,5 & 92,8 & $\begin{array}{l}3 \\
\end{array}$ & 84,3 & 89,5 & 85,4 & 81,0 & $\begin{array}{l}0 \\
\end{array}$ & $\begin{array}{l}3.87,7 \\
\end{array}$ & 88,5 & 82,1 & 84,0 & 88,8 & $\begin{array}{l}3 \quad 91,3 \\
\end{array}$ & \begin{tabular}{l|l}
3 & 87,3 \\
\end{tabular} & 81,2 & 2. 91,7 \\
\hline Food & 0 & 97,7 & 94,4 & 93,9 & 96,3 & 5,2 & 90,3 &, 3 & 89,3 & 87,5 & 86,0 & 5,3 & 86,8 & 86,5 & 86,7 & 85,4 & 86,6 & 86,4 & 88,2 & 86,6 & 88,6 \\
\hline &, 0 & 97,7 & 7,5 & 5,4 & 93,7 & 4 & 92,7 &, 3 & 87,2 & 7 & 85,2 & 7,9 & 2. 88,1 & 3,4 &, 9 & 0,9 & 9,3 & 89,8 & 92,3 & $3 \quad 91,2$ & 91,7 \\
\hline & 0,0 & 98,4 & 97,1 & 6,6 & 98,1 &, 1 & 98,6 & 7,4 & 98,1 & 97,6 & 97,2 & 296,6 & 6,1 & 95,7 & 5,6 & 94,0 & 94,1 & 5,4 & 96,3 & 96,3 & $\begin{array}{ll}3 \quad 97,0 \\
\end{array}$ \\
\hline Alcohol & 0,0 & 101,3 & 99,1 & 99,5 & 99,3 & 99,1 & 97,9 & 97,8 & $\begin{array}{l}37 \\
\end{array}$ & 97,0 & 96,2 & 2. 96,1 & 96,1 & 96,5 & 96,6 & 96,2 & 97,5 & 99,2 & 99,3 & 99,9 & 101,7 \\
\hline Tok & 0,0 & 91,3 & 84,8 & 90,2 & 90,2 & 91,1 & 90,0 & 134,3 & 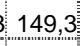 & 55,6 & 154,7 & 7151,6 & 151,7 & 151,4 & 155,6 & 156,9 & 156,3 & 145, & 145,5 & 145,3 & 145,6 \\
\hline Gaso & 100,0 & 98,9 & 101,4 & 100,4 & 103,0 & 102,3 & 102,7 & 130,3 & 131,0 & 148,7 & 164,6 & $\begin{array}{ll}6 \quad 163,9 \\
\end{array}$ & 164,9 & 9150,2 & 161,7 & 7) 152,4 & 143,7 & 137,7 & $\begin{array}{lll}7 & 150,1 \\
\end{array}$ & 149,8 & $\begin{array}{l}8 \\
\end{array}$ \\
\hline Pharmacy & 0,0 & 101 & 100,9 & 101 & 100,4 & 101,5 & 102,2 & 101,2 & 98 & 99,1 & 99,6 & $6 \quad 97,3$ & 96,8 & 103,4 . & 102,1 & 100,0 & 98,8 & 980 & 96,9 & 96,5 & 96,1 \\
\hline
\end{tabular}




\begin{tabular}{|c|c|c|c|c|c|c|c|c|c|c|c|c|c|c|c|c|c|c|c|c|c|}
\hline Ser & 00,0 & 108,2 & 108,6 & 108,9 & 110,3 & 112,4 & 113,3 & 113,1 & 112,6 & 113,1 & 113,4 & 114,2 & 115,0 & 116,1 & 116,4 & 116,5 & 117,0 & 117,0 & 117,7 & 116,9 & 117,7 \\
\hline & 0,0 & 2,6 & 101,5 & 102,1 & 104,7 & 123,3 & 123,3 & 123,3 & 123,3 & 123,3 & 123,3 & 123,3 & 123,3 & 123,2 & 123,2 & 123,2 & 123,2 & 123,3 & 123,3 & 123,3 & 123,3 \\
\hline & 0,0 & 101,3 & 3,8 & 103,1 & 101,4 & 1,7 & 3,1 & 102,9 & 2,1 & 101,8 & 4,4 & & 105,6 & 104,7 & 106,5 &, 5 & 105,7 & 5,8 & 107,0 & 05,9 & 06, \\
\hline & 0,0 & 100,0 & 100,0 & 100,0 & 113,7 & 4,8 & 5,6 & 173,6 & 2,0 & 171,6 & 173,0 & 73,9 & 175,8 & 176,4 & 177,6 & 177,5 & 179,3 & 187,3 & 204,3 & 201,2 & 207,4 \\
\hline & & 100,7 & 0,9 & 100,9 & 101,6 & 2,2 & 102,0 & 100,9 & 100,5 & 8,4 & 97,1 & 6,2 & 96,3 & 95,9 & 96,3 & 95,6 & 97,2 & 7,3 & 99,5 & 97,9 & 100,6 \\
\hline 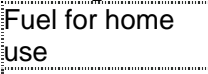 & & 1,9 & & & 1,3 & & 3,5 & 0,7 & & & 104,9 & & & 112,2 & 5,5 & 106,2 & 114,8 & 2,7 & 102,2 & 11 & 8,9 \\
\hline 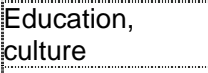 & 0 &, 6 & & 3 & 0,6 &, 5 &, 3 & 0 & 2 & 7 & 2,7 & 1 & 2 & 2 & 1 & 5 & 19,2 &, 2 & 123,0 & 123,2 & 123 \\
\hline ther goods & 00,0 & 100,3 & 100,7 & 100,7 & 100,3 & 100,0 & 9,5 & 9,1 & 0,0 & 3,9 & 90,4 & 95,4 & 95,0 & 90,3 & 93,0 & 96,1 & 97,5 & 91,0 & 90,4 & 97,7 & Yo, \\
\hline
\end{tabular}

As indicated in Table 4 by the end of 2002 the cumulative inflation of 8 groups of goods were higher than aggregate CPI inflation. At the same time cumulative inflation of 11 groups was lower than the aggregate CPI inflation.

Table 2.4: End-2002 Individual Inflation Indices, End-1997=100

\begin{tabular}{|c|c|c|c|}
\hline \multicolumn{3}{|c|}{ Sector/Group } & Market Characteristics \\
\hline \multirow{8}{*}{$\begin{array}{l}\text { Higher than } \\
\text { CPI inflation }\end{array}$} & Communication & 207,4 & Administrative price setting \\
\hline & Gasoline/diesel & 153,4 & Indirect taxes, \\
\hline & Tobacco & 145,6 & Indirect taxes, \\
\hline & Fuel for home use & 138,9 & Indirect tax, \\
\hline & Fruits and vegetables & 137,3 & Free, inelastic short term supply \\
\hline & Education, culture & 123,9 & Generally Free \\
\hline & Utilities & 123,3 & Administrative price setting \\
\hline & Services & 117,7 & Free \\
\hline \multirow{11}{*}{$\begin{array}{l}\text { Lower than CPI } \\
\text { inflation }\end{array}$} & Transport & 106,3 & Administrative price setting \\
\hline & Meat products & 103,5 & Free \\
\hline & Alcohol & 101,7 & Free, no changes in indirect taxes in reporting period \\
\hline & Clothing & 100,6 & Free \\
\hline & Other goods & 98,4 & Free \\
\hline & Non-alcohol drinks & 97,0 & Free \\
\hline & Pharmacy & 96,1 & Free, introduction of VAT in 2001 \\
\hline & Bread, cereals & 95,3 & Free, introduction of VAT in 1998 \\
\hline & Eggs and dairy & 91,7 & Free \\
\hline & Only imported food & 91,7 & Free, exchange rate \\
\hline & Food & 88,6 & Free, exchange rate \\
\hline
\end{tabular}

It is important to note that most of the groups for which the prices grow faster than CPI inflation over the period 1998-2002, are mostly goods with controlled prices. There are two exceptions: fruits/vegetables and services. On the other hand, the goods for which prices grow slower than CPI inflation, these are mostly "free" goods, with only exception being "transport". This group 
mainly consists of public transport, where the government has kept stable prices during 19982002.

However, there has been greater variability behind the cumulative indices as of the end of 2002. Figures 1-5 in the Annexes show cumulative indices of individual goods with base period of December 1997. Two main tendencies can be identified: administratively regulated prices have increased steadily, while most of the market determined prices have been steadily falling over 1997-2002 (in absolute and relative terms). The only exception is the "fruits and vegetables" group. As of 1998, 1999 and 2000 these prices have the lowest cumulative indices among the groups (Figures 1, 2 and 3 in the Annexes), reflecting deep decline of these prices in 1998-1999, while in 2001-2002 fruits and vegetable groups jumped to the upper lines of the list (Figures 4 and 5 in the Annexes).

So, in the time period under discussion there were two distinct developments in prices for agricultural (see figure 2.1): declining over the $1998-99$ by $30 \%$ and jumping in $2000-02$ to the index of 137 (end of 97=100).

Figure 2.1, 1998-02, 1997=100

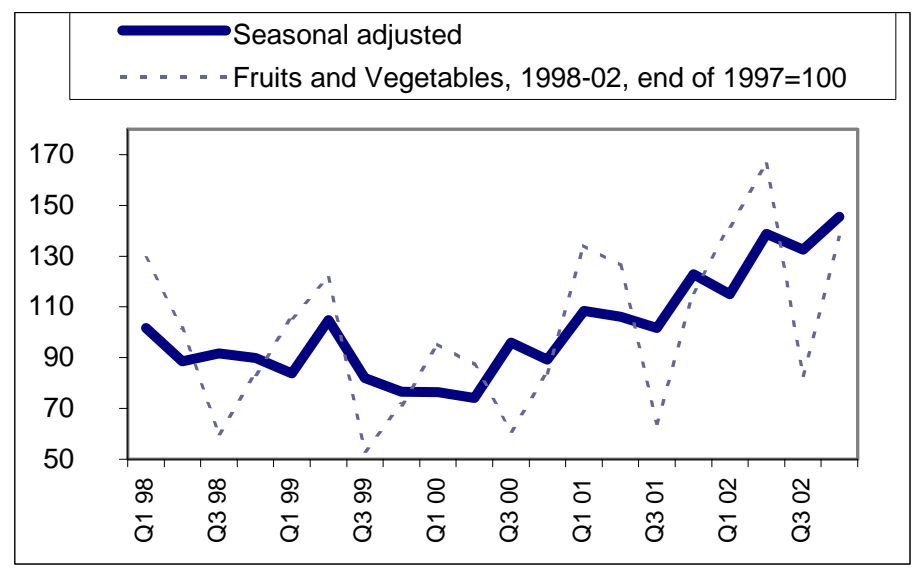

Identification of administratively regulated price changes. For empirical analysis we identify changes in administratively regulated prices (hereinafter ARP) for the period of 1998-2002. The following types of price changes can be identified as regulated price changes: direct revision of administratively controlled prices (such as utilities), introduction of VAT on goods that previously were not taxed by this indirect tax, and the increase/decrease of existing indirect taxes, in particular changes in excise tax statutory and effective rates. All these changes are 
policy variables and they can be aggregated as a combined impact of state regulation on the general price level. It is important to note that some cases of declining prices for excisable goods are also included in ARP as a negative contribution to CPI inflation. The rationale for this is that it is estimated that due to smuggling and inefficient tax administration, the effective rate of excise taxes for particular goods declined, causing downward price adjustment for some of excisable goods ${ }^{2}$. Such shifts also can be considered as a policy variable and consequently as a changes in ARP for our purposes.

The most significant ARP changes in the period of 1998-02 were: the introduction of VAT on bread in January 1998, an almost 30\% increase of electricity tariffs in January 1999, introduction of relatively heavy excises on tobacco and gasoline/diesel in August 1999, a second increase of excises on gasoline/diesel in 2000, increase of retail taxes on liquid gas in 2002 and frequent increases of telephone tariffs in 99-02. A number of incidents of declining prices for gasoline and tobacco in 2000-2002 also are included in this list.

\section{Price Variability: Initial Findings}

The following table summarizes different measures of variances of individual prices. I calculated variances of inflations for general CPI components, and as well as for goods that are in the "free" sector, which were never subject to any type of price regulation. The first variance (CPIVAR and FGVAR) measures the variability within individual inflations without taking into account the weights of each group. The table shows both seasonally adjusted and unadjusted variances (CPISAVAR and FGSAVAR). Since only the subgroup of "fruits and vegetables" is characterized with seasonality, it was seasonally adjusted using Census X11, while for other subgroups original unadjusted figures were taken. I have also calculated the Theil variance for seasonally adjusted data, which is recommended in a number of researches on relative prices.

Table 3.1

\begin{tabular}{|c|c|c|c|c|c|c|}
\hline \multirow{2}{*}{} & \multicolumn{2}{|c|}{ Cariances of all groups of } & \multicolumn{2}{l|}{ Variances of "free” goods } \\
\cline { 2 - 7 } & CPI VAR & CPI SA VAR & SA Theil VAR & FG VAR & FG SA VAR & FG SA Theil VAR \\
\hline 1998 Q1 & 58,98 & 17,32 & 35,52 & 74,74 & 8,16 & 4,8 \\
\hline
\end{tabular}

\footnotetext{
${ }^{2}$ In some quarters of 2000-2001 decline of prices for cigarettes are coupled with significant contraction of excise revenues from tobacco products, thus leading to a conclusion about declining effective rates.
} 


\begin{tabular}{|c|c|c|c|c|c|c|}
\hline 1998 Q2 & 28,59 & 14,77 & 16,9 & 39,15 & 17,2 & 18,05 \\
\hline 1998 Q3 & 92,4 & 5,07 & 6,24 & 135,92 & 3,4 & 4,56 \\
\hline 1998 Q4 & 86,51 & 12,4 & 4,34 & 126,70 & 2,9 & 2,27 \\
\hline 1999 Q1 & 191,47 & 170,62 & 53,61 & 63,47 & 9,18 & 4,29 \\
\hline 1999 Q2 & 16,61 & 38,89 & 58,02 & 26,46 & 62,28 & 57,58 \\
\hline 1999 Q3 & 353,37 & 199,01 & 226,84 & 263,35 & 43,26 & 191,31 \\
\hline 1999 Q4 & 82,2 & 26,18 & 20,08 & 109,37 & 9,35 & 12,92 \\
\hline 2000 Q1 & 71,63 & 14,35 & 8,08 & 102,55 & 3,55 & 18,63 \\
\hline 2000 Q2 & 15,5 & 12,27 & 6,06 & 8,85 & 4,29 & 12,67 \\
\hline 2000 Q3 & 48,21 & 50,18 & 77,35 & 73,96 & 80,12 & 76,37 \\
\hline 2000 Q4 & 84,56 & 24,77 & 16,79 & 114,12 & 16,5 & 13,95 \\
\hline 2001 Q1 & 206,77 & 42,12 & 43,08 & 292,67 & 42,51 & 46,16 \\
\hline 2001 Q2 & 11,5 & 9,84 & 7,15 & 8,61 & 6,3 & 9,87 \\
\hline 2001 Q3 & 128,44 & 4,2 & 3,12 & 202,20 & 4,07 & 4,03 \\
\hline 2001 Q4 & 342,66 & 29,11 & 35,92 & 531,50 & 36,93 & 38,13 \\
\hline 2002 Q1 & 32,59 & 37,63 & 25,87 & 41,82 & 18,76 & 39,99 \\
\hline 2002 Q2 & 30,61 & 37,42 & 39,55 & 28,02 & 38,89 & 39,33 \\
\hline 2002 Q3 & 138,46 & 12,74 & 10,83 & 200,74 & 10,76 & 9,22 \\
\hline 2002 Q4 & 241,57 & 41,19 & 21,6 & 344,07 & 18,89 & 15,2 \\
\hline
\end{tabular}

Figure 3.1 shows that seasonally unadjusted variance of all 19 components of CPI is strongly correlated with seasonally unadjusted variance within the group of "free" goods. This is explained by high fluctuations of fruits and vegetables prices.

Figure 3.1

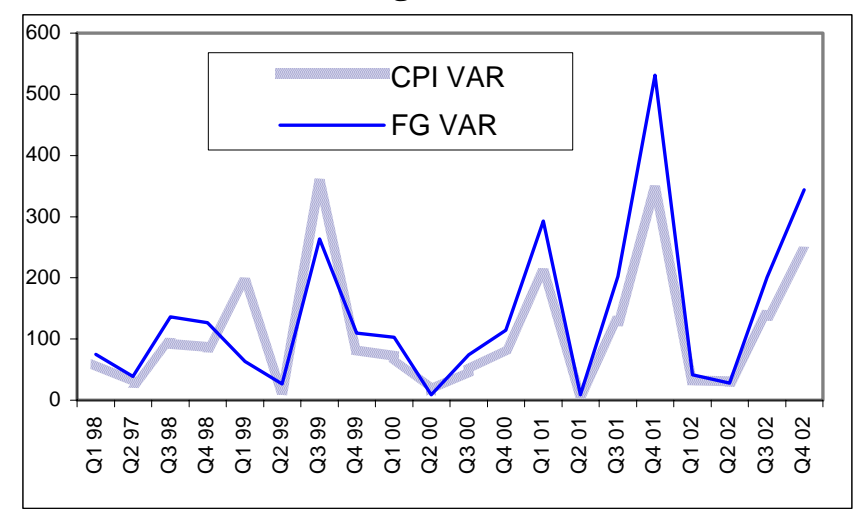


However, using seasonally adjusted data (SA CPI VAR and SA FG VAR), we will see that there are other factors explaining the variability within 19 groups of CPI basket, especially in 1999 (Figure 3.2).

Figure 3.2

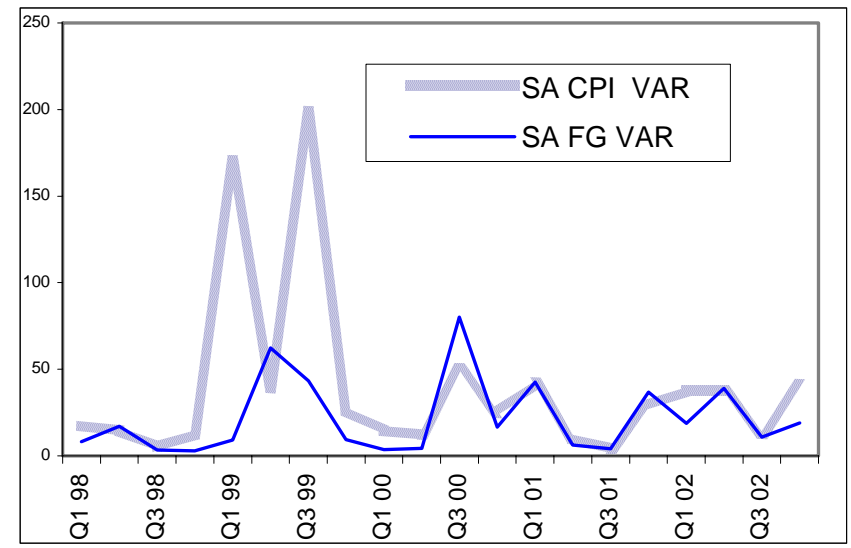

In Figure 3.3 the ARP and seasonally adjusted CPI price variability is presented, which shows that in the time of major price adjustments, ARP defines the scale of variability.

Figure 3.3

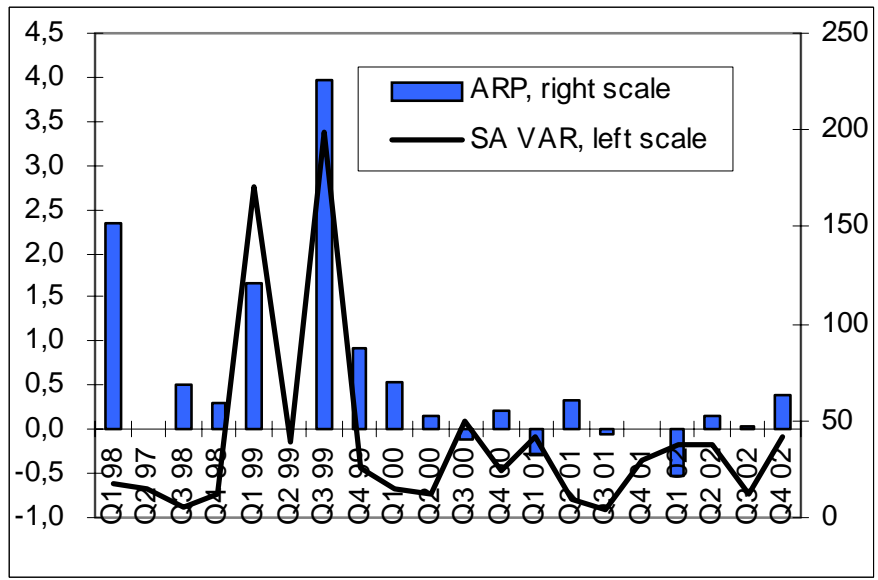

Data analyses show that despite of their weight of only 8.5\% in CPI basket (average weight for 1998-2002) agricultural goods had the greatest impact on price variability out of the set of "free" goods (Figure 3.4).

Figure 3.4 SA fruits and vegetables inflation and price variability (Theil) within "free" goods 


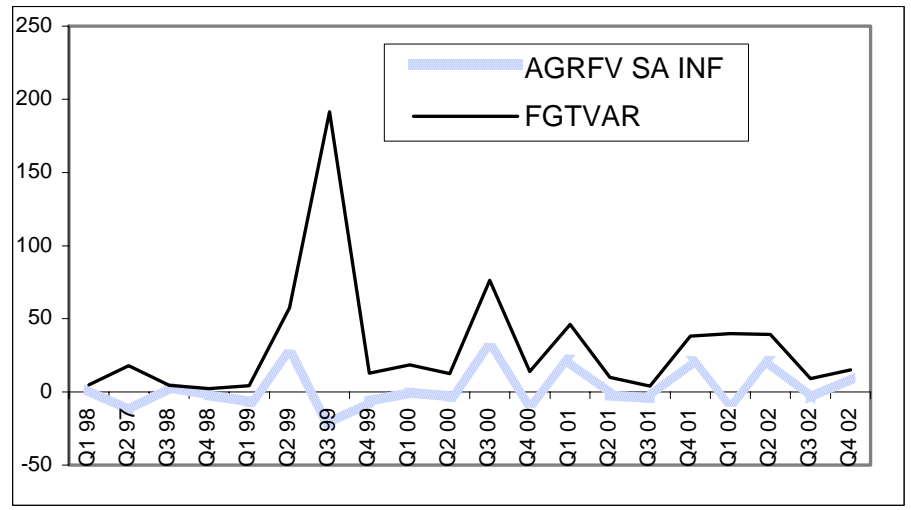

So, at this point we can conclude that the main factors affecting price variability are administratively regulated prices and fruits and vegetables. According to Figure 3.5, in 1998 and 1999 CPI inflation was lower than ARP contribution to CPI inflation, which means a drop of prices of "free" goods. In 2000 they were almost equal, which generally implies no significant change in the level of "free" prices. As for the following years (2001-02) when there was no significant contribution to CPI from ARP, CPI inflation was relatively high, reflecting increase in prices of "free" goods.

Figure 3.5

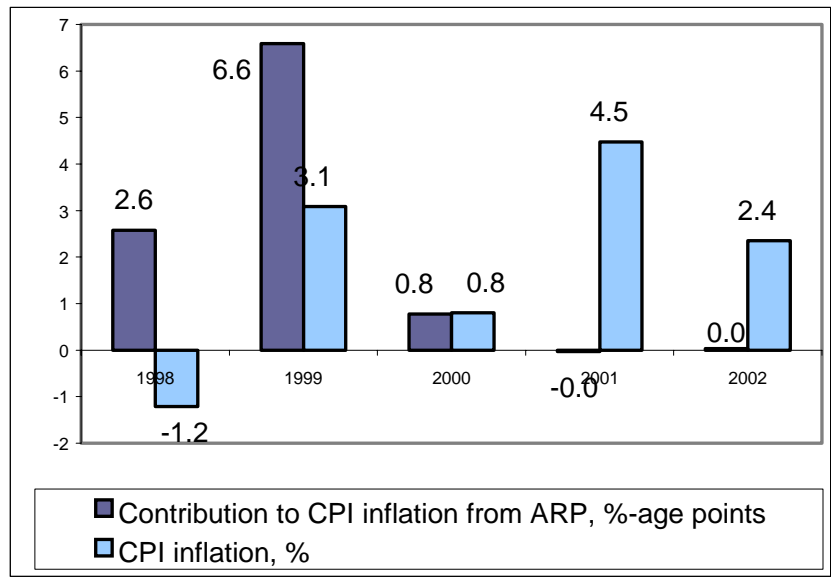

Figure 3.6 shows the contribution of fruits and vegetables prices to general inflation as percentage points of CPI inflation ${ }^{3}$.

Figure 3.6

\footnotetext{
${ }^{3}$ Weights of the group in CPI basket multiplied by individual inflation.
} 


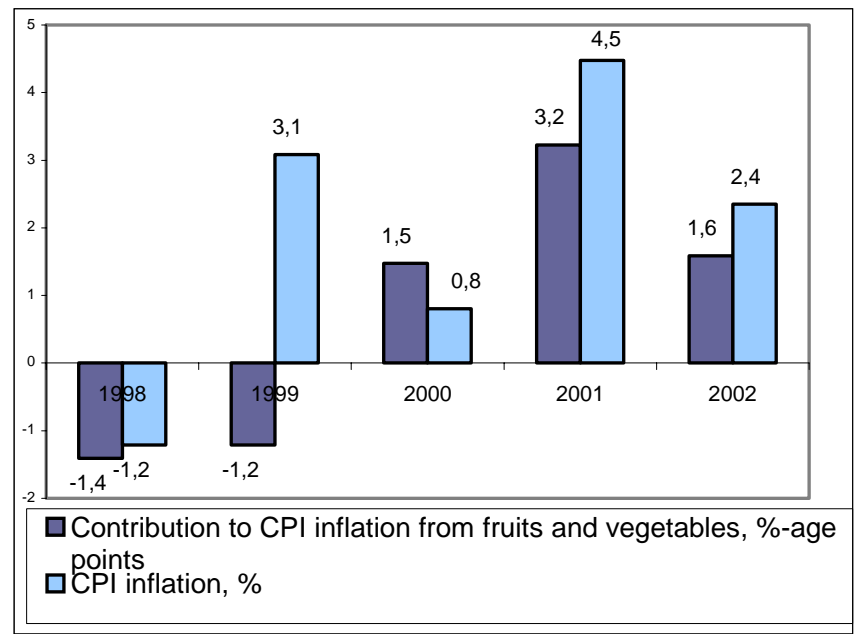

In 1998 and 1999 fruits and vegetables had negative contribution to CPI inflation, while in 2000 their contribution exceeded CPI inflation, which implies a reduction of prices for other "free" goods (note that the contribution of ARP was also positive in 2000, (see Figure 3.5)). In the following years fruits and vegetables made the biggest contribution to CPI inflation, contributing 3.2 and 1.6 percentage points out of respectively $4.5 \%$ and $2.4 \%$ CPI inflation. Figure 3.7 brings together contributions of both ARP and fruits and vegetables to CPI.

Figure 3.7

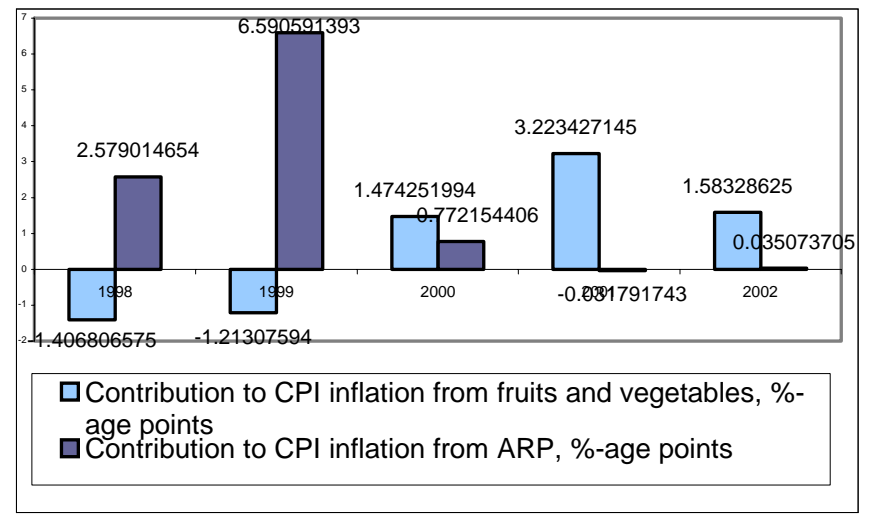

It is evident that during the most intense price adjustments period (1998-99) the prices for agricultural goods had declined and the opposite, in the time when prices of administratively regulated prices were generally stable, prices of fruits and vegetables jumped and significantly contributed to the total CPI inflation. 
For the purposes of this research we need to consider the concept of consistency ${ }^{4}$ between monetary policy and price adjustments. As Figure 3.8 shows in the time of major price adjustments (1998 and 1999) money supply growth was very moderate or money did not grow at all ${ }^{5}$. Meanwhile, at the time of absence of major controlled price adjustments, money growth was very strong.

Figure 3.8

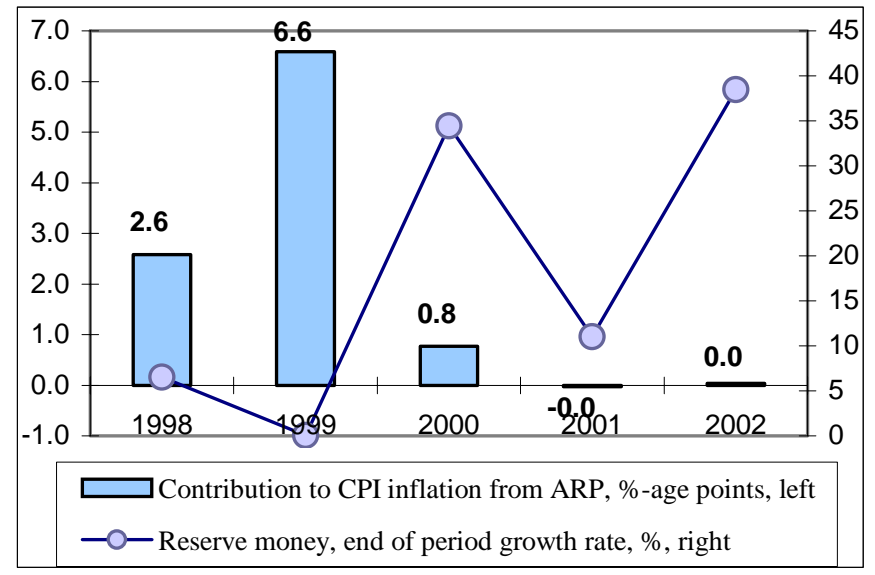

This pattern of money growth is explained by unique institutional design of the monetary policy. Due to conceptual changes in institutional relations of the Central Bank and the government, the amount of government liabilities against the central bank were frozen at the level of the end of 1997 (8.3 billion AMD). As a result of this the Central Bank is not able to manage the money stock through the purchases of Government's bonds. Thus the accumulation of the net foreign assets became practically the only tool of money expansion in the period of 1998-02. Since that time money supply resembles the dynamics of the net foreign assets of the Central Bank (see Figure 6 in Annexes), reflecting external sector developments such as volumes of remittances, export, external financing of the budget deficit and official "monetary" transfers to the state budget, volumes of used privatization proceeds. Under such circumstances the impact of the Russian crisis (decline of remittances from Russia, decline of export to CIS, portfolio capital outflows from the region) directly affected the money supply. The period of 1999-2000 was also

\footnotetext{
${ }^{4}$ The term of inconsistency between monetary policy and controlled price settings is given in Cukierman-Leidereman paper

${ }^{5}$ I am going to use a money supply indicator to test my hypothesis. This should probably be reserve money, as it is the policytied indicator. The share of foreign exchange deposits in broad money is quite large; therefore broad money doesn't properly reflect the monetary policy stance. However, to see of the impact on inflation, we probably need to exclude the reserve money growth resulting in reduction of the money velocity.
} 
characterized by delays of external financing of the state budget, which also prevented the growth of money supply. It is important to note that reserve money growth for 27 months was negative (December 1997 to April 2000).

As the main source of money expansion are foreign exchange purchases (external financing of the deficit and foreign grants) from government, the "power” of money in Armenia is very strong, as money expands only if there are foreign budget flows and these flows are spend by Government. So, increase in money supply is generally driven by higher budget deficit (directly financed by external financing) or higher domestic deficit (directly financed by official grants).

Income distribution implications. The sales of fruits and vegetables constitutes a significant share of rural income. This is the reason why the dynamics of fruits and vegetables prices also has very important implications for income distribution. Data on income distribution and poverty are available from the three household surveys conducted by National Statistical Service with the assistance of the World Bank. Table 5 shows the general picture of poverty in Armenia ${ }^{6}$.

Table 5

\begin{tabular}{|l|c|c|c|c|c|c|c|c|c|}
\hline & \multicolumn{4}{|c|}{ Total } & \multicolumn{3}{c|}{ Urban } & \multicolumn{3}{c|}{ Rural } \\
\cline { 2 - 11 } & 1996 & 1999 & 2001 & 1996 & 1999 & 2001 & 1996 & 1999 & 2001 \\
\hline Non-poor & 45.2 & 45.0 & 49.1 & 41.2 & 41.7 & 48.1 & 52.0 & 49.2 & 51.3 \\
\hline Poor & 54.8 & 55.1 & 50.9 & 58.8 & 58.3 & 51.9 & 48.0 & 50.8 & 48.7 \\
\hline Of which very poor & 27.7 & 22.9 & 16.0 & 29.6 & 23.2 & 18.3 & 24.4 & 22.6 & 14.0 \\
\hline
\end{tabular}

As the table shows the situation with poverty slightly worsened between the first 2 surveys of 1996 and 1999. It resulted from the increase of rural poverty by 2.8 percentage points, while urban poverty slightly declined between 1996 and 1999. Although extreme rural poverty declined in the period of 1996-99, we can suggest that this is not because of increase of rural factor income. In fact, the decline of extreme poverty is mostly attributed to the Government's new policy of social protection ${ }^{7}$. As no proper household surveys were organized in 1997 and 2000, it is impossible to keep track of poverty dynamics for these years. It is important to note that in the period of increase of rural poverty (1998-1999) prices of fruits and vegetables, which cover significant part of rural income, fell by cumulative $30 \%$. In addition to this, prices of meat

\footnotetext{
6 The following poverty lines were used: Poor Very Poor, Non-poor

${ }^{7}$ In 1998 family allowances were introduced and as it is widely recognized, it reduced the extreme poverty rate both in the urban and rural arrears
} 
products, bread and cereals, which also are important for rural income, dropped in this period as well.

\section{Theoretical Framework}

While most of the theoretical studies of the link between relative prices, inflation and monetary policy focus on the nature of association between relative price variability and inflation, during the last decade much research has focused on the role of monetary policy in avoiding negative effects of price adjustments on relative prices and the resulting income redistribution as well as losses of economic growth. This is significant in transition economies, which are characterized by major structural shifts and administrative price adjustments that can affect price variability. Coorey, Mecagni and Offerdal (1996 and 1997) have analyzed this issue and concluded that administrative price changes need to be partially or fully accounted for through higher inflation targets. The issue of price adjustments and their impact on relative prices has found its application in the design of monetary policies in a few transition countries. In particular, the Central Bank of the Czech Republic (NBC) implemented net inflation targeting in 1998-2001 (NBC reports, 1998, 1999, 2000, 2001), aiming at full or partial accommodation of expected price adjustments in the inflation target ${ }^{8}$.

Cukierman and Liederman (1984) developed a more comprehensive theoretical framework for the analysis of the impact of administrative price adjustments on relative prices. Cukierman and Liederman consider two sectors of an economy: a "free" sector, with market determined prices and a controlled sector, with administratively set prices are (the latter is viewed as a composite aggregate “controlled good”). The model illustrates the impact of changes in the price of controlled goods and monetary policy upon price formation in the "free" sector. 9

The rate of change of nominal money stock is described as:

$\Delta \mathrm{x}_{\mathrm{t}}=\mathrm{x}_{\mathrm{t}}-\mathrm{X}_{\mathrm{t}-1}=\mathrm{E}_{\mathrm{t}-1} \Delta \mathrm{x}_{\mathrm{t}-1}+\varepsilon_{\mathrm{t}}=\delta_{\mathrm{t}}+\varepsilon_{\mathrm{t}}$

\footnotetext{
${ }^{8}$ Hence having core inflation target of 2-4\% in 1998, and headline inflation target of 4.3-5.8\%, National Bank of Czech Republic tried to fully account for changes of price adjustments for a lower core inflation, and partially, for upper levels of core inflation.

${ }^{9}$ Here I briefly summarize the simplified version of the model used in Wozniak, "Relative Prices and Inflation in Poland 19891997”, Warsaw, December, 1997.
} 
Where $\delta_{\mathrm{t}}=\mathrm{E}_{\mathrm{t}-1} \Delta \mathrm{x}_{\mathrm{t}-1}$ is the expected (on the basis of information as of time t-1) money supply increase and $\varepsilon_{t}$ is a random normally distributed term, unknown in period $t$.

The main rfesult of the model is the following equation:

$\mathrm{p}_{\mathrm{t}}(\mathrm{v})-\mathrm{Q}_{\mathrm{ft}}=\left(\left(\mathrm{x}_{\mathrm{t}-1}+\delta_{\mathrm{t}}-\mathrm{p}_{\mathrm{t}}(\mathrm{c})\right)+\beta \varepsilon_{\mathrm{t}}+\rho \mathrm{w}_{\mathrm{t}}(\mathrm{v})\right.$

where $\mathrm{p}_{\mathrm{t}}(\mathrm{v})$ is the price of the good in a "free" market of $\mathrm{v}, \mathrm{Q}_{\mathrm{ft}}$ is the price level within the group of "free" goods, $\mathrm{p}_{\mathrm{t}}(\mathrm{c})$ is the price of the controlled good, $\mathrm{w}_{\mathrm{t}}(\mathrm{v})$ is the relative excess demand shock in market $\mathrm{v}$

$\left(w_{t}(v)=w_{t}^{d}(v)-w_{t}^{s}(v)\right.$ and is normally distributed over time and across markets).

This equation implies that in addition to factors traditionally assumed to have positive influence on relative price variability like excess demand shocks and unexpected movements in money stock, price variability is also affected by the term $\left(\left(\mathrm{x}_{\mathrm{t}-1}+\delta_{\mathrm{t}}-\mathrm{p}_{\mathrm{t}}(\mathrm{c})\right)\right.$ which is defined as the lack of synchronization between monetary policy and controlled prices.

Thus, the notion of the "lack of synchronization" or "inconsistency" indicates that if the monetary policy does not properly account for administrative price adjustments or does not revise its monetary targets, significant price adjustments or deregulation can cause negative demand shocks in certain "free" goods markets. Taking into account the differences in demand elasticity, this may result in increased price variability within the "free" goods sector.

As shown in the initial data analysis, lack of synchronization between regulated price adjustments and monetary policy may have led to demand shocks that caused increased variability of "free" goods' prices in Armenia. This variability within the "free" goods sector has been in large part due to the variability in prices of agricultural goods. In 1998-1999, with basically no increase in money supply and major regulated price adjustments, fruits and vegetables price declined, while in 2000-2002, with a very impressive growth in money supply and basically no regulated price adjustments, the prices of fruits and vegetables increased significantly. 
The general Cukierman-Leiderman framework can be applicable for studying price variability in Armenia. The first and the main hypothesis that we need to test is whether the "inconsistency" as defined above causes more variability of "free" prices in Armenia. The dependent variable of this hypothesis to be tested is the variability of "free" goods prices. The explanatory variable needs to proxy for the "inconsistency" between monetary policy and administrated price adjustments. The difference of core inflation and ARP contributions can be used as an explanatory variable. The rationale is that aggregate "free" goods inflation (core inflation) represents the stance of monetary policy ${ }^{10}$, and if the gap between ARP contribution and core inflation widens, this can be interpreted as an increase in "inconsistency". In the ideal case we would prefer to consider the lack of synchronization between the expected part of money supply and administered price adjustments (as suggested in the Cukierman-Leiderman model), however, proper estimation of expectations of money supply are not available ${ }^{11}$.

Further, while in the Cukierman-Leiderman model the "lack of synchronization" is between money supply and ARP as two policy instruments, in the case of using core inflation, we will instead have the difference between ARP (a policy instrument) and core inflation (a policy outcome). The problem is that, in times of constant money supply core inflation can be affected by $\mathrm{ARP}^{12}$. Thus, this relationship could mean an association, not a causal relationship, between variability in "free" goods prices and the magnitude of discrepancy between ARP and core inflation.

To understand what factors may there be behind this association we can look at this issue from the angle of changes in money velocity. Since administrated price adjustments such as changes in utility prices or increasing indirect taxes cause nominal GDP growth, they also cause an increase in money velocity, given that the money supply is unchanged. However, this increase in velocity will normally be insufficient to absorb the growth of transactions in the short run and there will be a contraction of nominal demand for certain "free" goods. This would mean declining prices for these goods. In an opposite situation if we have downward price adjustments

\footnotetext{
${ }^{10}$ While core inflation is believed to be mostly a monetary phenomenon there can be other factors affecting core inflation such as real exchange rate.

${ }^{11}$ It would not be appropriate to use the program levels of the money supply since in 1998-2002 the monetary programs have been frequently revised.

${ }^{12}$ The data show a negative correlation between ARP and core inflation (coefficient -0.33 ).
} 
or decline of indirect taxes and if the monetary targets do not account for these, positive demand shocks in the "free" goods sector may result, causing rising prices for certain goods. To support this line of argument we would need to examine the relationship between aggregate money velocity, core inflation and administratively regulated price changes. So, as the second hypothesis we would expect to see that money velocity is positively related to administrative prices and negatively to core inflation.

Further we will try to assess exactly how agricultural prices (in particular, fruits and vegetables, which are main driving factors behind large price variability within "free" goods) are affected by the level of synchronization between administered price adjustments and monetary policy. There are certain reasons why fruits and vegetables are the ones out of the list of "free" goods that are most affected by this inconsistency. First of all, since in the short term the supply of agricultural goods is fixed, they become more vulnerable to demand shocks. On the other hand, in case of positive excess demand shocks external competition may prevent the rise of prices, while fruits and vegetables are "artificially protected" against external competition due to absence of direct trade with competitive producers Turkey and Azerbaijan. Thus the third hypothesis would be that the prices of agricultural goods were negatively associated with administrative price adjustments and positively with money supply.

\section{Empirical Analysis}

We use the quarterly data on price indices of 19 groups of CPI constructed on the basis of data provided by the National Statistical Service. In terms of weights of individual prices in CPI in this paper constant weights (average weights for the period of 1998-2002) are used. As discussed in section 2 the category for fruits and vegetables has been seasonally adjusted using Census X11.

The dependent variable of the first hypothesis to be tested (mentioned in theoretical part) is the variability of "free" goods prices measured by the Theil variance (TVAR) ${ }^{13}$. TVAR gives a more accurate picture of relative price shifts than conventional and weighted measures. Unlike

\footnotetext{
${ }^{13}$ TVAR is equal to the weighted sum of squared deviations of the un-weighted individual rates from the aggregate inflation rate.
} 
weighted variance TVAR is zero when no relative price changes occur and at the same time unlike conventional variance TVAR accounts for the relative share of a sector in the index, giving more weigh to the variation of important prices.

FGTVAR $=\mathrm{C}_{1}+\mathrm{C}_{2}(\mathrm{FGINF}-\mathrm{ARP})^{2}$

where FGTVAR is the Theil variance of "free" goods prices, FGINF is core inflation and ARP is the administrative price contribution to CPI. The term on the right hand side is squared to neutralize the differences in signs. The regression output below quite strongly supports the hypothesis.

Table 5.1

\begin{tabular}{|c|c|c|c|c|}
\hline \multicolumn{5}{|c|}{$\begin{array}{l}\text { Dependent Variable: FGTVAR } \\
\text { Method: Least Squares } \\
\text { Date: 09/26/03 Time: } 21: 51 \\
\text { Sample(adjusted): } 1998: 1 \text { 2002:4 } \\
\text { Included observations: } 20 \text { after adjusting endpoints } \\
\end{array}$} \\
\hline Variable & Coefficient & Std. Error & t-Statistic & Prob. \\
\hline $\begin{array}{c}\mathrm{C} \\
(\mathrm{FGINF-ARP})^{\wedge} 2 \\
\end{array}$ & $\begin{array}{l}7.972987 \\
4.165299 \\
\end{array}$ & $\begin{array}{l}6.311590 \\
0.624027 \\
\end{array}$ & $\begin{array}{l}1.263230 \\
6.674872 \\
\end{array}$ & $\begin{array}{l}0.2226 \\
0.0000 \\
\end{array}$ \\
\hline $\begin{array}{l}\text { R-squared } \\
\text { Adjusted R-squared } \\
\text { S.E. of regression } \\
\text { Sum squared resid } \\
\text { Log likelihood } \\
\text { Durbin-Watson stat }\end{array}$ & $\begin{array}{r}0.712248 \\
0.696262 \\
23.65091 \\
10068.58 \\
-90.59320 \\
1.752236 \\
\end{array}$ & $\begin{array}{l}\text { Mean depe } \\
\text { S.D. depen } \\
\text { Akaike info } \\
\text { Schwarz cr } \\
\text { F-statistic } \\
\text { Prob(F-sta }\end{array}$ & $\begin{array}{l}\text { lent var } \\
\text { ent var } \\
\text { iterion } \\
\text { rion }\end{array}$ & $\begin{array}{l}30.96779 \\
42.91393 \\
9.259320 \\
9.358893 \\
44.55391 \\
0.000003 \\
\end{array}$ \\
\hline
\end{tabular}

The regression shows that a wider difference between core inflation and ARP corresponds to higher variability of "free” goods prices. Normally we would expect that ARP and core inflation are moving opposite to each other, as higher ARP will cause lower core inflation (if money is unchanged) and zero or negative ARP will cause higher core inflation. In both cases the (FGINFARP) ${ }^{2}$ will increase.

Here we need to ask a question that has been the subject of major theoretical discussions over the last decades: does the variability of relative prices positively affect inflation. If it does, the accuracy of the above equation may be questioned. For this purpose I tested the link between FGINF and FGTVAR (conventional argument) and also the link between squared FGINF and 
FGVTAR (to test whether variation in the inflation rate explains the variability of "free" goods prices). The regression results below show that both tests are rejected.

Table 5.2

\begin{tabular}{|c|c|c|c|c|}
\hline \multicolumn{5}{|c|}{$\begin{array}{l}\text { Dependent Variable: FGINF } \\
\text { Method: Least Squares } \\
\text { Date: 09/26/03 Time: 00:15 } \\
\text { Sample(adjusted): 1998:1 2002:4 } \\
\text { Included observations: } 20 \text { after adjusting endpoints } \\
\end{array}$} \\
\hline Variable & Coefficient & Std. Error & t-Statistic & Prob. \\
\hline $\begin{array}{c}\text { C } \\
\text { FGTVAR } \\
\end{array}$ & $\begin{array}{r}0.151553 \\
-0.001545 \\
\end{array}$ & $\begin{array}{l}0.496459 \\
0.009539 \\
\end{array}$ & $\begin{array}{r}0.305268 \\
-0.161921 \\
\end{array}$ & $\begin{array}{l}0.7637 \\
0.8732 \\
\end{array}$ \\
\hline $\begin{array}{l}\text { R-squared } \\
\text { Adjusted R-squared } \\
\text { S.E. of regression } \\
\text { Sum squared resid } \\
\text { Log likelihood } \\
\text { Durbin-Watson stat }\end{array}$ & $\begin{array}{r}0.001454 \\
-0.054020 \\
1.784397 \\
57.31332 \\
-38.90678 \\
2.104911\end{array}$ & $\begin{array}{l}\text { Mean depe } \\
\text { S.D. depen } \\
\text { Akaike info } \\
\text { Schwarz cr } \\
\text { F-statistic } \\
\text { Prob(F-sta }\end{array}$ & $\begin{array}{l}\text { dent var } \\
\text { ent var } \\
\text { riterion } \\
\text { erion }\end{array}$ & $\begin{array}{l}0.103720 \\
1.738069 \\
4.090678 \\
4.190251 \\
0.026218 \\
0.873172\end{array}$ \\
\hline
\end{tabular}

Table 5.3

\begin{tabular}{|c|c|c|c|c|}
\hline \multicolumn{5}{|c|}{$\begin{array}{l}\text { Dependent Variable: FGTVAR } \\
\text { Method: Least Squares } \\
\text { Date: 09/24/03 Time: } 21: 34 \\
\text { Sample(adjusted): } 1998: 1 \text { 2002:4 } \\
\text { Included observations: } 20 \text { after adjusting endpoints } \\
\end{array}$} \\
\hline Variable & Coefficient & Std. Error & t-Statistic & Prob. \\
\hline $\begin{array}{c}\mathrm{C} \\
\mathrm{FGINF}^{\wedge} 2 \\
\end{array}$ & $\begin{array}{l}18.36817 \\
4.373959 \\
\end{array}$ & $\begin{array}{l}13.01993 \\
3.139432 \\
\end{array}$ & $\begin{array}{l}1.410774 \\
1.393233 \\
\end{array}$ & $\begin{array}{l}0.1754 \\
0.1805 \\
\end{array}$ \\
\hline $\begin{array}{l}\text { R-squared } \\
\text { Adjusted R-squared } \\
\text { S.E. of regression } \\
\text { Sum squared resid } \\
\text { Log likelihood } \\
\text { Durbin-Watson stat }\end{array}$ & $\begin{array}{r}0.097342 \\
0.047194 \\
41.88906 \\
31584.48 \\
-102.0257 \\
1.590758 \\
\end{array}$ & $\begin{array}{l}\text { Mean depe } \\
\text { S.D. depen } \\
\text { Akaike info } \\
\text { Schwarz cr } \\
\text { F-statistic } \\
\text { Prob(F-sta }\end{array}$ & $\begin{array}{l}\text { lent var } \\
\text { ent var } \\
\text { iterion } \\
\text { rion }\end{array}$ & $\begin{array}{l}30.96779 \\
42.91393 \\
10.40257 \\
10.50214 \\
1.941097 \\
0.180517\end{array}$ \\
\hline
\end{tabular}

I tested also the link between squared ARP and FGTVAR, which produced a statistically significant results $\left(\mathrm{R}^{2}=0.59\right)$. However, although this result is very impressive itself, the outcome of equation (3) is much stronger, which implies that "free" goods variability is better explained by the squared discrepancy between administrative price changes and aggregate "free" goods inflation, rather than with any single explanatory variable. 
For testing whether the mechanism of impact of monetary policy and price adjustment can be described through the velocity channel as assumed in theoretical section (the second hypothesis) I introduce the following equation.

$\log ($ VELOCITSA $)=C_{1}+C_{2}(A R P)+C_{3}($ FGINF $)(4)$

Where VELOSITSA is nominal GDP divided by reserve money, and seasonally adjusted. The reason for not taking broad money instead is that broad money includes foreign exchange nominated deposits, which does not have the same money power as reserve money. The logic behind of taking the Log of dependent variable is that it is an absolute figure, while explanatory variables are growth rates. Other variables are as previously defined.

Table 5.4

\begin{tabular}{|c|c|c|c|c|}
\hline \multicolumn{5}{|c|}{$\begin{array}{l}\text { Dependent Variable: LOG(VEL } \\
\text { Method: Least Squares } \\
\text { Date: 09/26/03 Time: 01:34 } \\
\text { Sample: 1998:1 2002:4 } \\
\text { Included observations: } 20 \\
\end{array}$} \\
\hline Variable & Coefficient & Std. Error & t-Statistic & Prob. \\
\hline C & 1.433363 & 0.019922 & 71.94822 & 0.0000 \\
\hline ARP & 0.038193 & 0.018300 & 2.087048 & 0.0523 \\
\hline FGINF & -0.016771 & 0.010968 & -1.529029 & 0.1447 \\
\hline R-squared & 0.384138 & \multicolumn{2}{|c|}{ Mean dependent var } & 1.451552 \\
\hline Adjusted R-squared & 0.311684 & \multicolumn{2}{|c|}{ S.D. dependent var } & 0.092776 \\
\hline S.E. of regression & 0.076972 & \multicolumn{2}{|c|}{ Akaike info criterion } & -2.153276 \\
\hline Sum squared resid & 0.100719 & \multicolumn{2}{|c|}{ Schwarz criterion } & -2.003917 \\
\hline Log likelihood & 24.53276 & \multicolumn{2}{|l|}{ F-statistic } & 5.301794 \\
\hline Durbin-Watson stat & 1.178900 & \multicolumn{2}{|c|}{ Prob(F-statistic) } & 0.016241 \\
\hline
\end{tabular}

The results are presented in the table 5.4. Although R-squared is not very impressive, the signs and significance of coefficients were robust to changing time periods and specifications.

While equation (3) shows general link between variability of "free” goods prices and lack of policies synchronization, we need to take our arguments further and see how agricultural goods prices (as a main driving force behind “free” goods variability) are affected by these policies. For this I estimate the following equation. 
Where AGRFVSA is a seasonally adjusted aggregate price index for fruits and vegetables, and MONEY is reserve money. The reason of not taking conventional money supply aggregates such as lagged broad money, is that because of absence of traditional (interest rate) transmission mechanism in Armenia. The Central Bank can increase money supply only by conversion of budget foreign exchange nominated loans and grants, which immediately are being spent by government. So, any particular level of reserve money generally reflects the size of government's spending in that period, thus having strong direct demand management implication, as it could be in the case of fiscal policy. This is the main reason why I believe I can take reserve money indicator without lagging it. Regression output is presented below.

Table 5.5

\begin{tabular}{|c|c|c|c|c|}
\hline \multicolumn{5}{|c|}{$\begin{array}{l}\text { Dependent Variable: LOG(AGRFVSA) } \\
\text { Method: Least Squares } \\
\text { Date: 09/26/03 Time: 01:34 } \\
\text { Sample: 1998:2 2002:4 } \\
\text { Included observations: } 19 \\
\end{array}$} \\
\hline Variable & Coefficient & Std. Error & t-Statistic & Prob. \\
\hline $\begin{array}{c}\text { C } \\
\text { ARP } \\
\text { LOG(MONEY) }\end{array}$ & $\begin{array}{r}-2.286775 \\
-0.041445 \\
0.625647\end{array}$ & $\begin{array}{l}1.526447 \\
0.033116 \\
0.137986\end{array}$ & $\begin{array}{r}-1.498103 \\
-1.251526 \\
4.534126\end{array}$ & $\begin{array}{l}0.1536 \\
0.2287 \\
0.0003\end{array}$ \\
\hline $\begin{array}{l}\text { R-squared } \\
\text { Adjusted R-squared } \\
\text { S.E. of regression } \\
\text { Sum squared resid } \\
\text { Log likelihood } \\
\text { Durbin-Watson stat }\end{array}$ & $\begin{array}{l}0.630236 \\
0.584015 \\
0.132052 \\
0.279004 \\
13.13936 \\
1.489845\end{array}$ & $\begin{array}{l}\text { Mean depe } \\
\text { S.D. depen } \\
\text { Akaike info } \\
\text { Schwarz cr } \\
\text { F-statistic } \\
\text { Prob(F-stat }\end{array}$ & $\begin{array}{l}\text { dent var } \\
\text { ent var } \\
\text { riterion } \\
\text { erion }\end{array}$ & $\begin{array}{r}4.597473 \\
0.204742 \\
-1.067301 \\
-0.918179 \\
13.63542 \\
0.000349\end{array}$ \\
\hline
\end{tabular}

As it was assumed, coefficients of ARP and LOG(MONEY) have opposite signs, supporting our assumption about the mechanism of influence of administratively controlled prices and monetary policy. We also tested the same equation adding the price level of fruits and vegetables lagged by one quarter. Results are presented in the below table.

Table 5.6

Dependent Variable: LOG(AGRFVSA)

Method: Least Squares

Date: 09/26/03 Time: 01:34

Sample: 1998:2 2002:4 


\begin{tabular}{|c|c|c|c|c|}
\hline Variable & Coefficient & Std. Error & t-Statistic & Prob. \\
\hline $\begin{array}{c}\text { C } \\
\text { ARP } \\
\text { LOG(MONEY) } \\
\text { LOG(AGRFVSA(-1)) } \\
\end{array}$ & $\begin{array}{r}-1.059511 \\
-0.060630 \\
0.273390 \\
0.582472 \\
\end{array}$ & & & $\begin{array}{l}0.4531 \\
0.0542 \\
0.1416 \\
0.0172 \\
\end{array}$ \\
\hline $\begin{array}{l}\text { R-squared } \\
\text { Adjusted R-squared } \\
\text { S.E. of regression } \\
\text { Sum squared resid } \\
\text { Log likelihood } \\
\text { Durbin-Watson stat }\end{array}$ & $\begin{array}{l}0.749813 \\
0.699775 \\
0.112184 \\
0.188778 \\
16.85059 \\
2.693576 \\
\end{array}$ & \multicolumn{2}{|c|}{$\begin{array}{l}\text { Mean dependent var } \\
\text { S.D. dependent var } \\
\text { Akaike info criterion } \\
\text { Schwarz criterion } \\
\text { F-statistic }\end{array}$} & $\begin{array}{r}4.597473 \\
0.204742 \\
-1.352693 \\
-1.153864 \\
14.98504 \\
0.000088\end{array}$ \\
\hline
\end{tabular}

Although my research also intends to estimate the impact of relative price variability on income distribution, this cannot be done through regular statistical methods, since we have data on income distribution and poverty only for three discrete points in time.

\section{Conclusions and Policy Implications}

Based on the theoretical background and empirical analysis, I can conclude the main findings of the paper that if monetary policy does not account for changes in administrative prices, demand in "free" goods market will shift causing fluctuation of prices for agricultural goods. 1998-1999 was a period when major administrative price adjustments (introduction of VAT on bread, increase of electricity tariffs, substantial increases of excise taxes on tobacco, gasoline and diesel) coincided with super-tight monetary policy, which caused depressed agricultural prices. In the following years, strong money expansion coincided with absence of major administrative price adjustments (moreover, because of smuggling and tax evasion the prices of a number of excisable goods declined). This situation led to a recovery of agricultural prices, which exceeded the pre-1999 level in 2002.

This volatility of prices may have had some income distribution implications. In particular, while between 1996-1999 general poverty incidence in the country stayed stable, rural poverty significantly increased. As I showed in the paper, major decline of agricultural prices started in 1998 and continued throughout 1999. Later, the recovery of the prices could contribute to improvement of rural households' living standards that was recorded in 2001. 
As an evaluation of the Government's design of the regulated price adjustments in 2001-2002, we can conclude that Government has lost the opportunity to implement some price adjustments in 2001-2002 without negative consequences for "free" goods prices, as these years were a time of strong aggregate demand and money expansion. Now, postponed price adjustments are in the near policy agenda. Major price adjustments also are expected due to closure of the Armenian Nuclear Power Plant (implying higher tariffs for electricity) and introduction of VAT on agricultural goods, as a requirement for WTO admission. Estimates show that combined effect of these changes will be more than $1.5 \%$ annually contribution of administratively regulated prices to CPI inflation over the medium-term. Given that Central Bank monetary targets are designed to keep inflation below 3\%, we can anticipate that variability within the group of "free" goods will increase, with possible decline of agricultural goods' prices.

To summarize, if major price adjustments are underway and the country is not endangered by possibilities of high inflation (high one digit and above) due to favorable institutional design (sustainable budget deficit, absence of Central Bank's direct crediting to the Government), monetary policy must be designed to account for administrative price adjustments. In particular, it can not be reasonably justified that having 2 percentage points pressure on CPI from long postponed administratively regulated prices, the country should maintain headline CPI below $3 \%$. Core inflation targeting could be a very useful mechanism to avoid lump-sum impact of price adjustments on "free" price variability and resulting losses in predictability of markets and uncertainty. Even if a country has a core inflation targeting, price adjustments could cause negative demand shocks in certain "free" goods markets resulting in lower than projected core inflation outcome and greater variability of "free" prices. To avoid this, monetary policy should adjust its policy tools in the time of major price adjustments. 


\section{Annexes:}

Figure 1, price level of end of $1997=100$

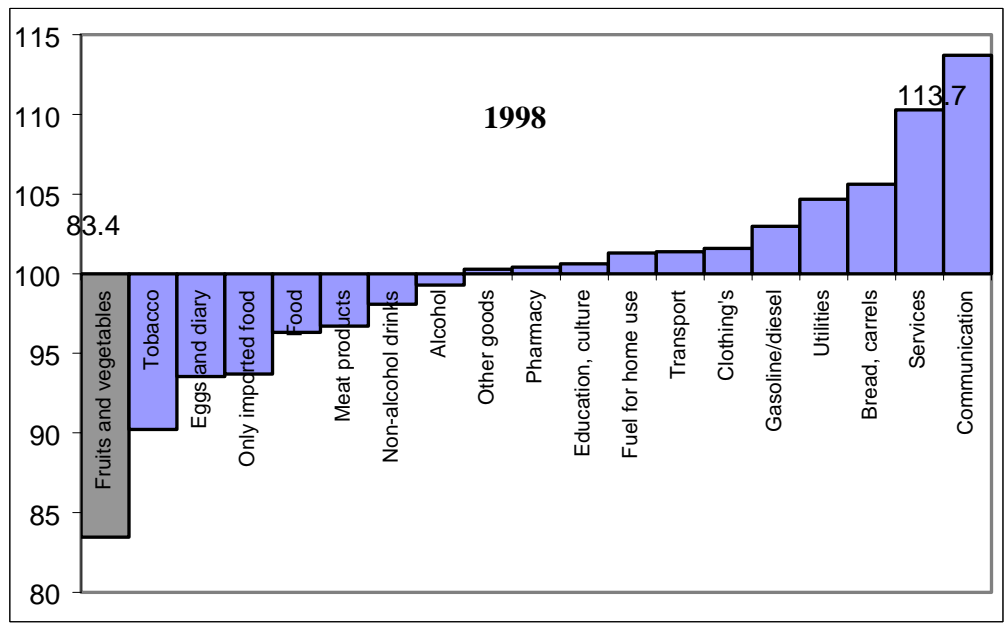

Figure 2, price level of end of 1997=100

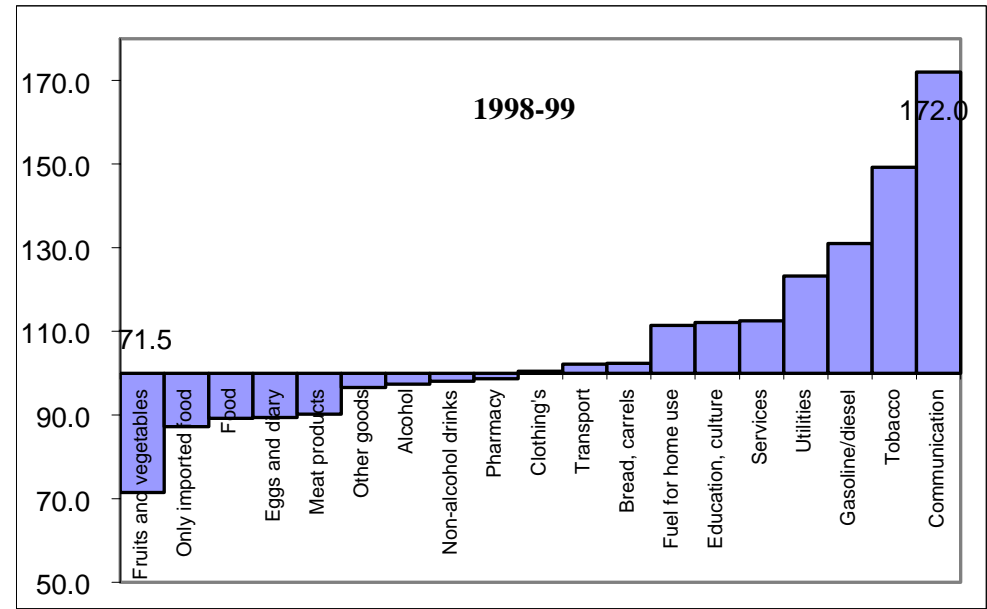

Figure 3, price level of end of $1997=100$

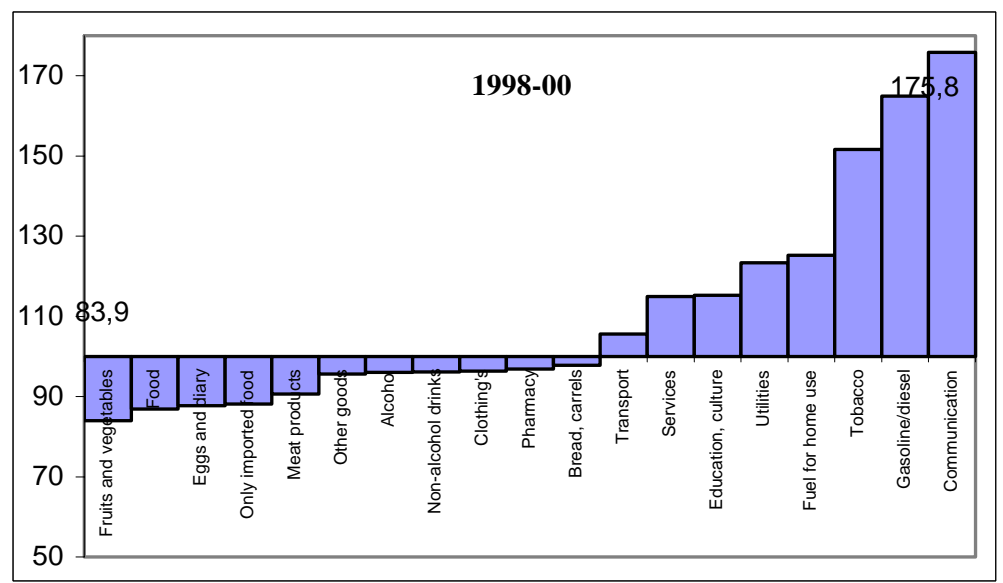


Figure 4, price level of end of $1997=100$

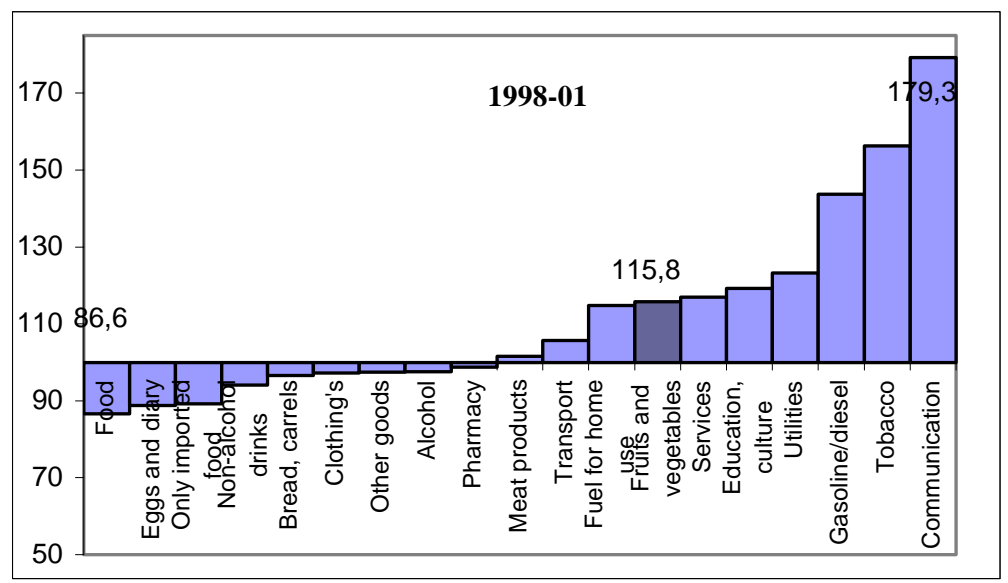

Figure 5, price level of end of $1997=100$

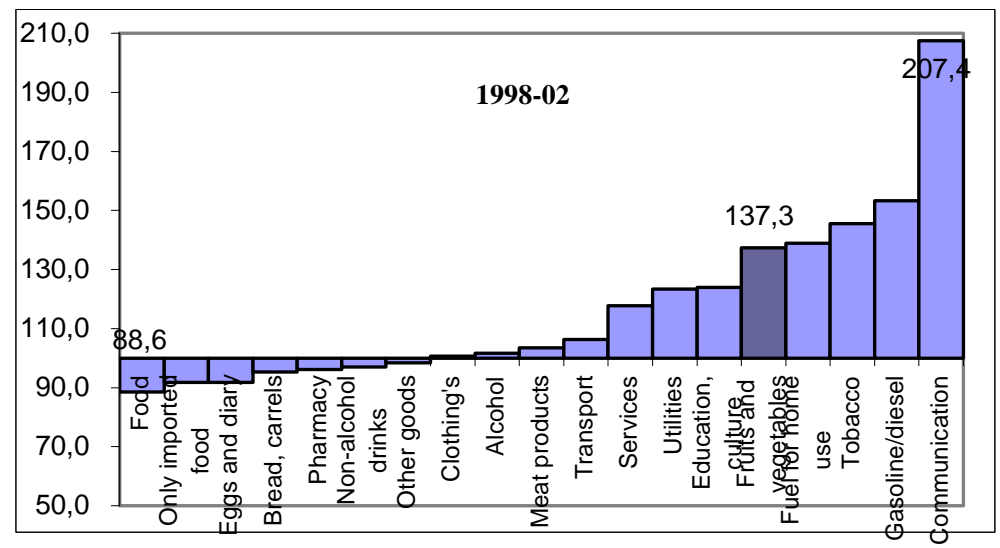

Figure 14, Money creation pattern in 1998-2002

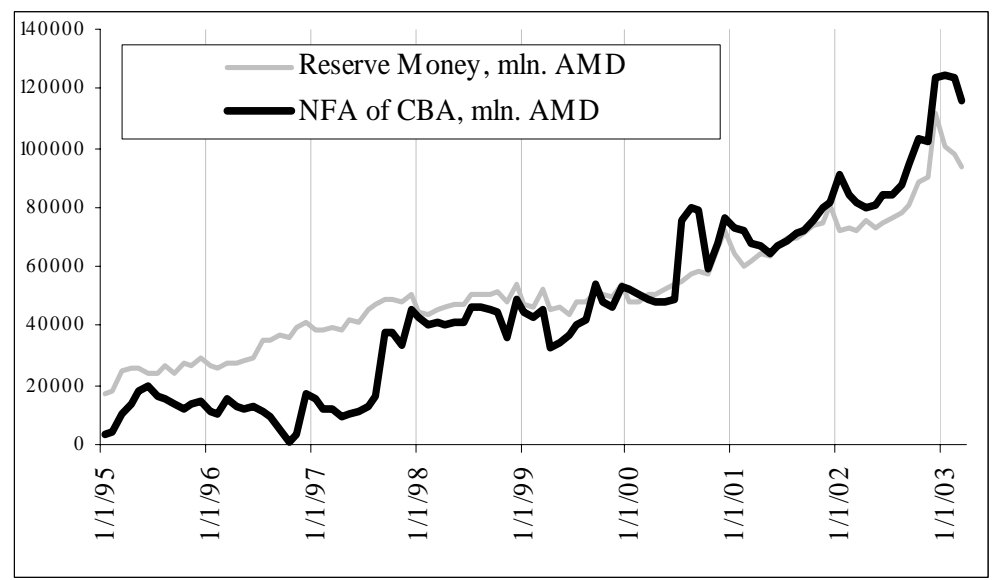




\section{Bibliography}

Ales Bulir, (1998), Does Inflation Matter? WP/98/7, (Washington, International Monetary Fund, January, 1998)

Artish R. Ghosh, (1997), Inflation in Transition Economies: How much? And Why?, WP/97/80, (Washington, International Monetary Fund, July, 1997)

Artish R. Ghosh and Steven Phillips, (1998), Inflation, Disinflation, and Growth, WP/98/68, (Washington, International Monetary Fund, May, 1998)

Ball, L. and N. G. Mankiw, (1994), Asymmetric Price Adjustments and Economic Fluctuations, Economic Journal, Vol. 104 (March 1, 1994)

Ball, L. and N. G. Mankiw, Relative Price Changes as Aggregate Supply Shocks, The quarterly Journal of Economics, Vol. 110, Issue 1

Cecchetti, S. and R. Rich (2001), “Structural Estimates of the U.S. Sacrifice Ratio”, Journal of Business and Economic Studies, 19, 4: pp. 416-424,

Coorey, S., Mecagni, M. and Offerdal, E., (1996), Disinflation in Transition Economies: The Role of Relative Price Adjustment, WP/96/138, (Washington, International Monetary Fund, December)

Coorey, S., Mecagni, M. and Offerdal, E., (1997), Designing Disinflation programs in Transition Economies: The Implications of Relative Price Adjustment, PPAA/97/1, (Washington, International Monetary Fund, February, 1997)

Cukierman, Alex, (1983), Relative Price Variability and Inflation: A Survey and Further Results, Carnegie-Rochester Conference Series on Public Policy, 19 (1983) pp 103-158

Cukierman, A. and Leiderman (1982) Price Controls and the Variability of Relative Prices, Money, Credit and Banking, Vol. 16, No. 3 (August 1994) 
Giovanni Andrea Cornia (1999), Liberalization, Globalization and Income Distribution, UNU/WIDER project "Rising Income Inequality and Poverty Reduction: Are they Compatible?”, (Helsinki, March 1999)

Jacek Cukrowski, George Kavelashvili, (2002), Inflation and Adjustment of Relative Prices in Georgia CASE Working Paper No 42

Paul Cashin, Paolo Mauro, Catherine Pattillo, and Ratna Sahay, (2001) Macroeconomic Policies and Poverty: Stylized Facts and an Overview of Research WP/01/135, (Washington, International Monetary Fund, 2001)

Sarel, Michael, (1995) Nonlinear Effects of Inflation on Economic Growth, WP/95/56, (Washington, International Monetary Fund, June, 1995)

Sarel, Michael (1995), Relative prices, Economic Growth and Tax Policy, WP/95/113, (Washington, International Monetary Fund, November, 1995)

Wozniak, P., (1997) Relative Price and Inflation in Poland 1989- 1997, Studies and Analyses, Center for Social and Economic Research, No.121 (Warsaw, December 1997)

Wozniak, P., (1998) Relative Price Adjustments in Poland, Hungary and the Czech Republic. Comparison of the Size and Impact on Inflation, Center for Social and Economic Research, Working Paper No.12, 1998 (Warsaw, August 1998)

Zavoico, B., (1995) “A Brief Note on the Inflationary process in Transition Economies”, 1995 (Mimeo) 


\section{DAVIDSON INSTITUTE WORKING PAPER SERIES - Most Recent Papers}

The entire Working Paper Series may be downloaded free of charge at: www.wdi.bus.umich.edu

CURRENT AS OF 12/6/2004

\begin{tabular}{|c|c|c|}
\hline Publication & Authors & Date \\
\hline $\begin{array}{l}\text { No. 732: Measuring the Institutional Change of the Monetary Regime } \\
\text { in a Political Economy Perspective }\end{array}$ & $\begin{array}{l}\text { Nikolay Nenovsky and Yorgos } \\
\text { Rizopoulos }\end{array}$ & Dec. 2004 \\
\hline $\begin{array}{l}\text { No. 731: Impact of Regulated Price Adjustments on Price Variability in } \\
\text { a Very Low Inflation Transition Economy: Case of Armenia }\end{array}$ & Aghassi Mkrtchyan & Nov. 2004 \\
\hline $\begin{array}{l}\text { No. 730: Reform, FDI and Economic Growth: Tale of the Tortoise and } \\
\text { the Hare }\end{array}$ & $\begin{array}{l}\text { Bruno Merlevede and Koen } \\
\text { Schoors }\end{array}$ & Nov. 2004 \\
\hline $\begin{array}{l}\text { No. 729: The Effects of Transition and Political Instability On Foreign } \\
\text { Direct Investment Inflows:Central Europe and the Balkans }\end{array}$ & $\begin{array}{l}\text { Josef C. Brada, Ali M. Kutan, } \\
\text { and Taner M. Yigit }\end{array}$ & Nov. 2004 \\
\hline $\begin{array}{l}\text { No. 728: Institutional Distance and International Business Strategies } \\
\text { in Emerging Economies }\end{array}$ & $\begin{array}{l}\text { Delia Ionascu, Klaus E. Meyer, } \\
\text { and Saul Erstin }\end{array}$ & Nov. 2004 \\
\hline No. 727: Explaining Patterns of Corruption in the Russian Regions & $\begin{array}{l}\text { Phyllis Dininio and Robert W. } \\
\text { Orttung }\end{array}$ & Nov. 2004 \\
\hline $\begin{array}{l}\text { No. 726: The Politics of Institutional Learning and Creation: Bank } \\
\text { Crises and Supervision in East Central Europe }\end{array}$ & Gerald A. McDermott & Nov. 2004 \\
\hline $\begin{array}{l}\text { No. 725: International Business and Development Economics: A } \\
\text { Winning Combination }\end{array}$ & Tamir Agmon & Nov. 2004 \\
\hline $\begin{array}{l}\text { No. 724: Importing High-Risk Capital and Revealing Hidden } \\
\text { Comparative Advantages }\end{array}$ & Tamir Agmon & Oct. 2004 \\
\hline $\begin{array}{l}\text { No. 723: Which entrepreneurs expect to expand their businesses? } \\
\text { Evidence from survey data in Lithuania }\end{array}$ & $\begin{array}{l}\text { is and Tomasz } \\
\text { icz }\end{array}$ & Oct. 2004 \\
\hline No. 722: Russia from Bust to Boom: Oil, Politics or the Ruble? & \begin{tabular}{|l|} 
Bruno Merlevede and Koen \\
Schoors \\
\end{tabular} & Oct. 2004 \\
\hline No. 721: Distanc & $\begin{array}{l}\text { Klara Sabirianova Peter, Jan } \\
\text { Svejnar, and Katherine Terrell }\end{array}$ & Sept. 2004 \\
\hline $\begin{array}{l}\text { No. 720: An Analysis of Gender Wage Differentials in Russia from } \\
\text { 1996-2002 }\end{array}$ & Rita Hansberry & Sept. 2004 \\
\hline $\begin{array}{l}\text { No. 719: Returns to Schooling in Russia and Ukraine: } \\
\text { A Semiparametric Approach to Cross-Country Comparative Analysis }\end{array}$ & $\begin{array}{l}\text { Peter and } \\
\text { nko }\end{array}$ & Sept 2004 \\
\hline $\begin{array}{l}\text { No. 718: The emergence of lar } \\
\text { firms: Evidence from Poland at }\end{array}$ & Irena Grosfeld and Iraj Hashi & Aug. 2004 \\
\hline $\begin{array}{l}\text { No. 717: Wage Determination Under Communism and In Transition: } \\
\text { Evidence from Central Europe }\end{array}$ & $\begin{array}{l}\text { Basu, Saul Estrin and Jan } \\
\text { ar }\end{array}$ & Aug. 2004 \\
\hline No. 716: The Evolution of Cross-Region Price Distribution in Russia & Konstantin Gluschenko & July 2004 \\
\hline $\begin{array}{l}\text { No. 715: Languages in the European Union: The Quest for Equality and } \\
\text { its Cost }\end{array}$ & $\begin{array}{l}\text { Jan Fidrmuc and Victor } \\
\text { Ginsburgh }\end{array}$ & July 2004 \\
\hline $\begin{array}{l}\text { No. 714: Voice of the Diaspora: An Analysis of Migrant Voting } \\
\text { Behavior }\end{array}$ & Jan Fidrmuc and Orla Doyle & July 2004 \\
\hline $\begin{array}{l}\text { No. 713: International Coercion, Emulation and Policy Diffusion: } \\
\text { Market-Oriented Infrastructure Reforms, 1977-1999 }\end{array}$ & $\begin{array}{l}\text { Witold J. Henis } \\
\text { Zelner and Mau }\end{array}$ & July 2004 \\
\hline $\begin{array}{l}\text { No. 712: Votes and Vetoes: The Political Determinants of Commercial } \\
\text { Openness }\end{array}$ & $\begin{array}{l}\text { Witold J. Henisz and Edward D. } \\
\text { Mansfield }\end{array}$ & July 2004 \\
\hline $\begin{array}{l}\text { No. 711: Interest Groups, Veto Points and Electricity Infrastructure } \\
\text { Deployment }\end{array}$ & $\begin{array}{l}\text { Witold J. Henisz and Bennet A. } \\
\text { Zelner }\end{array}$ & July 2004 \\
\hline $\begin{array}{l}\text { No. 710: Firms' Price Markups and Returns to Scale in Imperfect } \\
\text { Markets: Bulgaria and Hungary }\end{array}$ & \begin{tabular}{|l|} 
Rumen Dobrinsky, Gábor Körösi, \\
Nikolay Markov, and László \\
Halpern \\
\end{tabular} & July 2004 \\
\hline $\begin{array}{l}\text { No. 709: The Stability and Growth Pact from the Perspective } \\
\text { of the New Member States }\end{array}$ & Gábor Orbán and György Szapáry & July 2004 \\
\hline $\begin{array}{l}\text { No. 708: Contract Violations, Neighborhood Effects, and Wage Arrears } \\
\text { in Russia }\end{array}$ & $\begin{array}{l}\text { John S. Earle and Klara } \\
\text { Sabirianova Peter } \\
\end{array}$ & July 2004 \\
\hline $\begin{array}{l}\text { No. 707: Determinants of Employment Growth at MNEs: Evidence } \\
\text { from Egypt, India, South Africa and Vietnam }\end{array}$ & $\begin{array}{l}\text { Sumon Kumar Bhaumik, Saul } \\
\text { Estrin and Klaus Meyer }\end{array}$ & July 2004 \\
\hline
\end{tabular}

